\title{
A FLUORESCENT MICROSCOPIC STUDY OF ADRENERGIC INNERVATION OF THE APPENDIX IN RABBITS AND CATS
}

\author{
M. SIROŤÁKOVÁ ${ }^{1}$, M. KOČIŠOVÁ ${ }^{2}$, K. SCHMIDTOVÁ ${ }^{2}$, M. KUCHTA $^{1}$, F. DORKO ${ }^{2}$ \\ ${ }^{1}$ Institute of Experimental Medicine, ${ }^{2}$ Institute of Anatomy, Medical Faculty, P. J. Šafárik University, \\ Košice, Slovak Republic \\ This paper is dedicated to the life jubilee of Dr. Stopek, CSc. \\ Received February 24, 2000 \\ Accepted July 27, 2000 \\ Abstract \\ Sirotáková, M., M. Kočišová, K. Schmidtová, M. Kuchta, F. Dorko: A Fluorescent \\ Microscopic Study of Adrenergic Innervation of the Appendix in Rabbits and Cats. Acta Vet. Brno \\ 2000, 69: 173-176. \\ The authors studied the innervation of the appendix in rabbits and cats. Adrenergic nerve \\ components in rabbits were visualized by glyoxylic acid histofluorescence method and in cats by \\ the method of formol-induced fluorescence of catecholamines and 5-HT. \\ Adrenergic nerve components enter the appendix in the investigated species "from outside" in \\ a common bundle with arteries and line these vessels in the form of plexiform bundles of nerve \\ profiles as far as their terminal ramification in the organ wall. Nerve fibres, supplying both the \\ longitudinal and circular layer of the wall musculature, branch away from the periarterial plexuses \\ as well as nerve profiles entering the neuropil between neurocytes of myenteric and submucous \\ plexuses. Moreover, they form loose plexuses of nerve fibres in the lamina muscularis mucosae \\ and penetrate the mucosal glands. In the interdomal regions they finally branch out to loose and \\ irregular plexuses of very delicate nerve profiles. \\ In both species, the highest density of specifically fluorescent neural components is recorded in \\ the compartmens of submucosa and mucosa, lying out of aggregated lymphoid follicles, whereas \\ these fibres do not penetrate into the follicles, or B-dependent parts.
}

Adrenergic nerves, lymphoid tissue, vermiform process

In the literary data reporting on the nerve supply of different parts of the gastrointestinal tract (GIT), attention of researchers has been paid to the study of solitary and aggregated lymphoid follicles of the GIT (Felten 1993; Felten et al. 1981). It is known that the CNS by means of autonomous nervous system influence also the functions of lymphoid organs (Felten 1993). Therefore, it is evident that the study of the appendix innervation is not the object of only marginal interest.

Whereas in some animal species appendix is entirely absent, in others (e.g. cats) it is extremely small, comma-shaped, the initial part of the colon ascendens, while in the rabbit is well developed. Some specificities of acetylcholinesterase (AChE)-positive and butyrylcholinesterase (BuChE)-positive innervation of lymphoid components are associated with certain species-specific features of this organ (Sirotáková et al. 1996). Therefore, there is a question whether the analogous findings also characterize the adrenergic components of nerve supply of this organ in rabbits and cats, as representatives of laboratory animal species.

\section{Materials and Methods}

Clinically healthy adult animals of both sexes were used in the study. The appendices of 12 rabbits (Chinchilla, body mass $2.5-3.5 \mathrm{~kg}$ ) and 15 cats (from the quarantine asylum, body mass $1.8-2.5 \mathrm{~kg}$ ) were examined. Before experiments, the animals were reared in the Central Animal Husbandry quarters under veterinary care. All animals

Address for correspondence:

MVDr. Mária Sirotáková, CSc.

Medice of Experimental

Tr. SNP 1,04066 Košice, Slovak Republic 
were anaesthetized with thiopental $\left(50-60 \mathrm{mg} \cdot \mathrm{kg}^{-1} \mathrm{IP}\right)$. Constantly, multiple tissue specimens were collected from every organ. Adrenergic nerve components in rabbits were visualized by the glyoxylic acid histofluorescence method (Shalev and Zhuckova 1987) and in cats by the method of formol-induced fluorescence of catecholamines and 5-HT (Falck and Owman 1965). At that, next histological sections were stained with hematoxylin-eosin, thionine, acridine orange, silver-impregnations methods.

Both the fluorescent microscopic examination and photographic documentation were performed using the Jenalunar 2 (Zeiss, Jena).

\section{Results}

In both examined animal species, the adrenergic nerve components enter the appendix in a common bundle with arteries in the form of typically carrying periarterial and so-called "adventitial" plexuses that line these vessels as far as their terminal compartments of ramification in the organ wall. In the intramural topography, not many nerve fibres branch away from the adrenergic plexuses to the outer and inner muscular layer of the wall, not excluding the components of myenteric and submucous plexuses. In this topography in cats, the individual nerve profiles, branching away from them, are intensively fluorescent. In these compartments of submucosa and mucosa lying out of lymphoid tissue, the density of adrenergic nerve components appears to be the highest (Plate IV, Figs 1a,b). In addition, in the lamina muscularis mucosae and also around basal compartment of glands in the stroma of mucous villi, the thin network aggregations of nerve fibres are intensively fluorescent in both species of animals (Plate IV, Figs 2a,b).

In the rabbit submucosa and mucosa, small and large piriform lymphoid follicles, aggregated close side by side and predominantly in one row, are abundantly represented. Large lymphoid follicles with their basal compartments often get to the close vicinity of the inner muscular layer (Plate V, Fig. 3), whereas all the structural components of submucosa, including vessels and nerves, are pressed away partially aside, partially toward the mucosal surface into very narrow interfollicular septa (Plate V, Fig 4). Adrenergic nerve components, however, can be reliably identified in all the pressed away and displaced periarterial plexuses round the lymphoid tissue as well as in interfollicular septa. Within dilated interdomal regions of mucosa, a specific fluorescence of delicate nerve profiles is less piercing, but is entirely absent only in those parts that have signs of progressive regressive changes. These terminal nerve formations do not occur in cats.

It is evident that specifically fluorescent adrenergic nerve components of the appendix are aggregated in the vicinity of lymphoid tissue and they do not usually penetrate into the follicles; they enter only their marginal layers.

\section{Discussion}

From the morphological view, the neural control of all functional compartments of the gastrointestinal tract is realized through the autonomic nervous system that ensure outer interconnections of the digestive system with the CNS centres as well as the enteral nervous system (ENS) itself. The ENS is considered as an independent nerve system being able to programme and coordinate the GIT functions independently of directive impulses from the CNS (Costa et al. 1987; Jabbur et al. 1988).

Specifically fluorescent postganglionic adrenergic nerve bundles and fibres enter the appendix together with AChE-positive preganglionic and afferent viscerosensitive components in the shape of typical carrying periarterial nerve plexuses that line these vessels also in the intramural topography as far as their terminal ramifications (Felten et al. 1981). They represent a very conspicuous component of histological findings because they contain a considerable amount of preterminal and terminal fibres with piercingly fluorescent varicosely dilated parts that are considered for transformation of directive nerve 
impulses for certain quantities of a released neurotransmitter. As in the presented topographies the synaptic clefts are mostly not large, the adrenergic innervation of arteries is in the category of directly sympathetic-regulated components of GIT. The same is also true of veins, even if veins are evidently deficiently adrenergically supplied (Felten 1993; Carlson et al. 1987).

The role of adrenergic nerve fibres, branching away from carrying periarterial nerve plexuses and running among smooth muscular cells of longitudinal and circular layer of the musculature of the digestive tube wall as well as gangliocytes of submucous and myenteric plexuses, is mainly joined with influencing the gastrointestinal motility.

Terminal compartments of prevailing majority of adrenergic and AChE-positive enteral neurons lie in the close vicinity of the target effector components of GIT ensuring digestive processes (Wood 1981ab). In the appendix as well as in other intestinal compartments, thin nerve branches and fibres run outside the solitary and aggregated lymphoid follicles and do not enter inside them. They occur in the parafollicular or interfollicular and so-called interdomal T-dependent topography of the lymphoid tissue. As it is known, $\mathrm{T}$ and B lymphocytes belong to the category of continuously migrating cells and just their re-circulation appears to be a basic precondition of specific effectiveness of lymphocyte-mediated organism defence (Kordon and Bihoreau 1989; Sicard 1986; V an Tits et al. 1990). Migration of lymphocytes is also connected with "supervision" of all regions of potential presentation of antigens (Felten 1993). Delicate nerve fibres are present in the interdomal region together with numerous cellular elements, including mastocytes, and they participate in modulation of humoral and cellular response of the organism.

Our findings are in agreement with those of other authors (Felten 1993; Felten et al. 1981) regarding the fact that adrenergic nerve profiles innervate all the structural components of the appendix wall, whereas they predominantly lie aside or around lymphoid follicles, and they do no penetrate their inner B-dependent compartments.

It is known that appendix is a well organized region of lymphoid tissue and its adrenergic innervation represents only one way from many possibilities for communications between the CNS and the immune system.

\section{Adrenergická inervácia appendixu králikov a mačiek, sledovaná pomocou fluorescentnej mikroskopie}

Autori študovali inerváciu apendixu u králikov a mačiek. Adrenergické nervové súčasti u králikov znázorňovali pomocou fluorescenčnej histochemickej metódy s kyselinou glyoxylovou a u mačiek metódou formolom indukovanej fluorescencie katecholamínov a 5-HT.

Adrenergické nervové súčasti vstupujú do apendixu u vyšetrovaných druhov zvonku v spoločnom zväzku s artériami a lemujú tieto cievy v podobe plexiformných zoskupení nervových profilov až po ich koncové rozvetvenia $v$ stene orgánu. $Z$ periarteriálnych plexov odbočujú priebežne nervové vlákna, ktoré zásobujú longitudinálnu a cirkulárnu vrstvu svaloviny steny, d'alej tiež nervové profily vstupujúce do neuropilu medzi neurocytmi plexus myentericus a submucosus. Okrem toho utvárajú riedke splete nervových vláken v lamina muscularis mucosae a prenikajú i k slizničným žliazkam. V interdomálnych oddieloch sa napokon rozkonárujú na riedke a nepravidelné splete velmi jemných nervových profilov.

U obidvoch vyšetrovaných druhov sa najväčšia hustota špecificky fluoreskujúcich nervových súčasti zaznamenáva $\mathrm{v}$ tých oddieloch podsliznice a sliznice, ktoré ležia pomimo folliculi lymphatici aggregati, pričom tieto vlákna dovnútra folikulov, resp. Bdependentných oddielov neprenikajú. 


\section{References}

CARLSON, S. L., FELTEN, D. L., LIVNAT, S., FELTEN, S. Y. 1987: Noradrenergic sympathetic innervation of the spleen: V. Acute drug-induced depletion of lymphocytes in the target fields of innervation results in redistribution of noradrenergic fibres by the maintance of compartmentation. J. Neurosci. Res. 18: 64-67

COSTA, M., FURNESS, J. B., ILLEWELLYN-SMITH, J. 1987: Histochemistry of enteric nervous system. Physiol. Gastroent. Tract 1: 1-39

FALCK, B., OWMAN, CH. 1965: A detailed methodological description of the fluorescence method for cellular demonstration of biogenic monoamines. Acta Univ. Lund. 7: 1-23

FELTEN, D. L. 1993: Direct innervation of lymphoid organs: Substrate for neurotransmitter signaling cells of the immune system. Neuropsychobiology 28: 110-112

FELTEN, D. L., OVERHAGE, J. M., FELTEN, S. Y., SCHMEDTJE, J. F. 1981: Noradrenergic sympathetic innervation of lymphoid tissue in the rabbit appendix: Further evidence for a link between the nervous and immune systems. Brain Res. Bull 7: 595-612

JABBUR, S. J., EL-KAK, F. H., NASSAR, C. F. 1988: The enteric nervous system: An overview. Med. Res. Rev. 8: 459-469

KORDON, C., BIHOREAU, C. 1989: Integrated communication between the nervous, endocrine and immune systems. Hormon. Res. 31: 100-104

SICARD, R. E. 1986: Hormones, neurosecretions, and growth factors as signal molecules for intercellular communication. Develop. Comp. Immunol. 10: 269-272

SIROŤÁKOVÁ, M., BÁNOVSKÁ, E., KOČIŠOVÁ, M., STOPEK, D. 1996: Histochemical activity AChE and $\mathrm{BuChE}$ in neural and non-neural parts of processus vermiformis in some mammals. Folia Med. Cass. 53: 37-46 (in Slovak)

SHVALEV, V. N., ZHUCKOVA, N. 1987: An improvement in histochemical findings in adrenergic nervous element in glyoxylic acid solutions with the aid of dimethylsulphoxide (DMSO).Arch. Anat. 93: 91-92

VAN TITS, L. J. H., MICHEL, M. C., GROSSE-WILDE, H., HAPPEL, M., EIGLER, F. W., SOLIMAN, A., BRODDE, O. E. 1990: Catecholamines increase lymphocyte $\beta_{2}$ - adrenergic receptors via a $\beta_{2}$-adrenergic, spleen-dependent process. Am. J. Physiol. 258: 191-202

WOOD, J. D. 1981a: Intrinsic neural control of intestinal motility. Am. Rev. Physiol. 43: 33-51

WOOD, J. D. 1981b: Synaptic interactions in the enteric plexuses. J. Autonom. Nerv. System 4: 121-133 
Plate IV

Sirotáková M. et al.: A Fluorescent... pp. 173-176
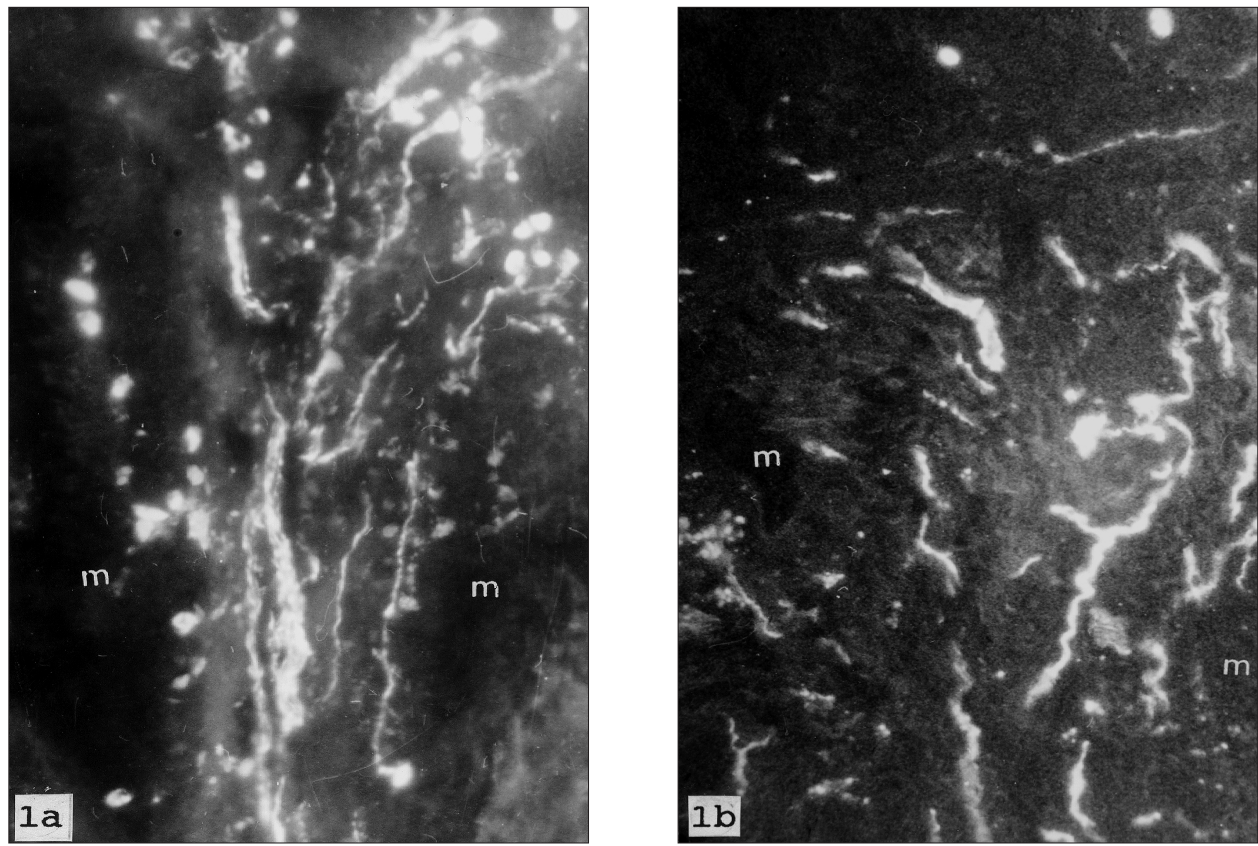

Fig. 1a,b. In the superficial interdomal mucous layer, lying aside the peridomal moat (m), occurrence of adrenergic nerve profiles is relatively abundant in (a) rabbit and (b) cat. Primary magnification: $\times 120$
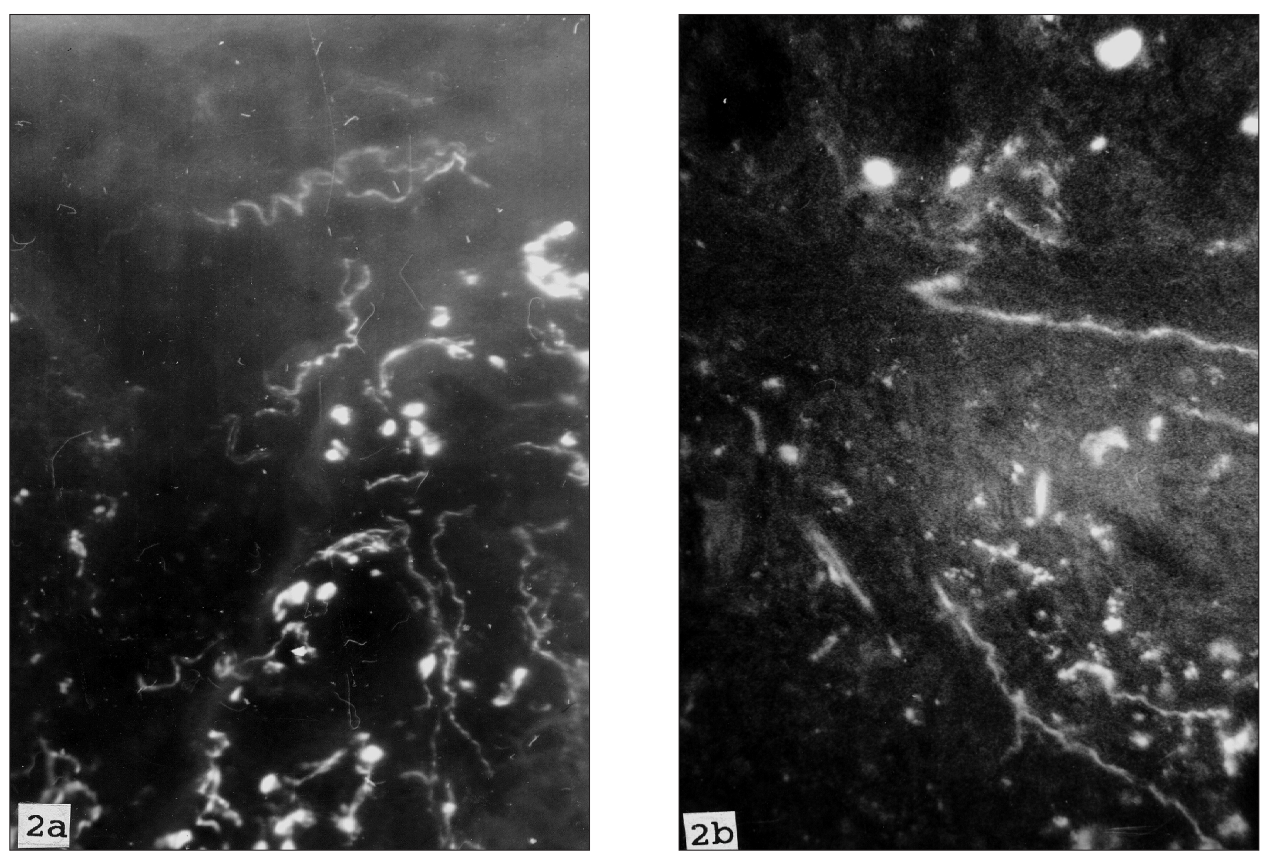

Fig. 2 a,b. A characteristic appearance of richly branched specifically fluorescent adrenergic fibres in the interdomal region in rabbit (a) and cat (b). Primary magnification: $\times 120$ 
Plate V

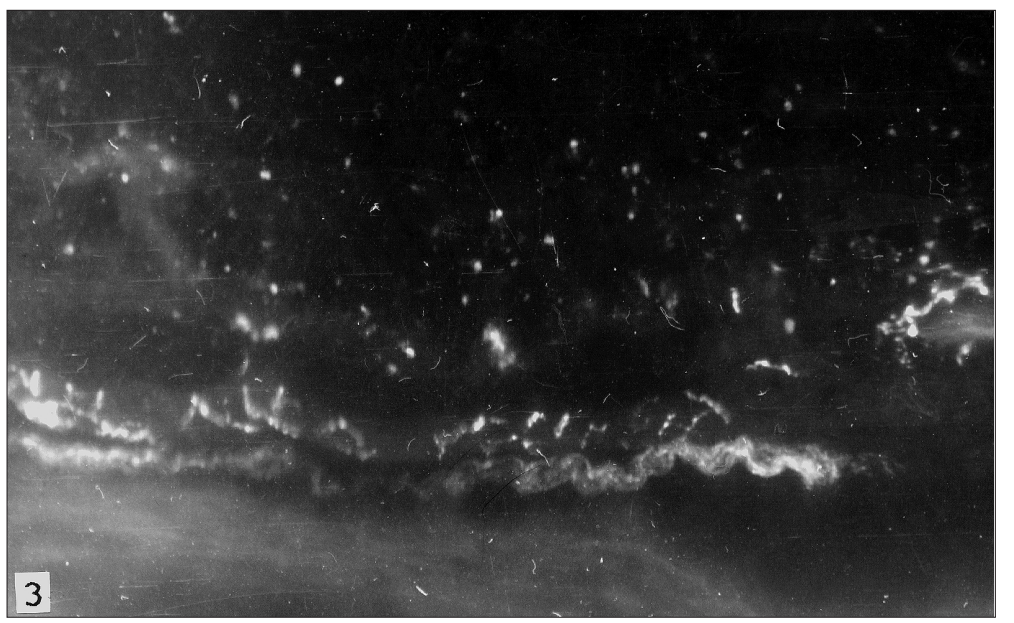

Fig. 3. Abundant occurrence of specifically fluorescent nerve bundles and fibres, lying in the close vicinity of circular muscular layer, may be occasionally recorded in the compressed narrow layer of submucosa at the base of lymphoid follicle in rabbits. Primary magnification: $\times 120$

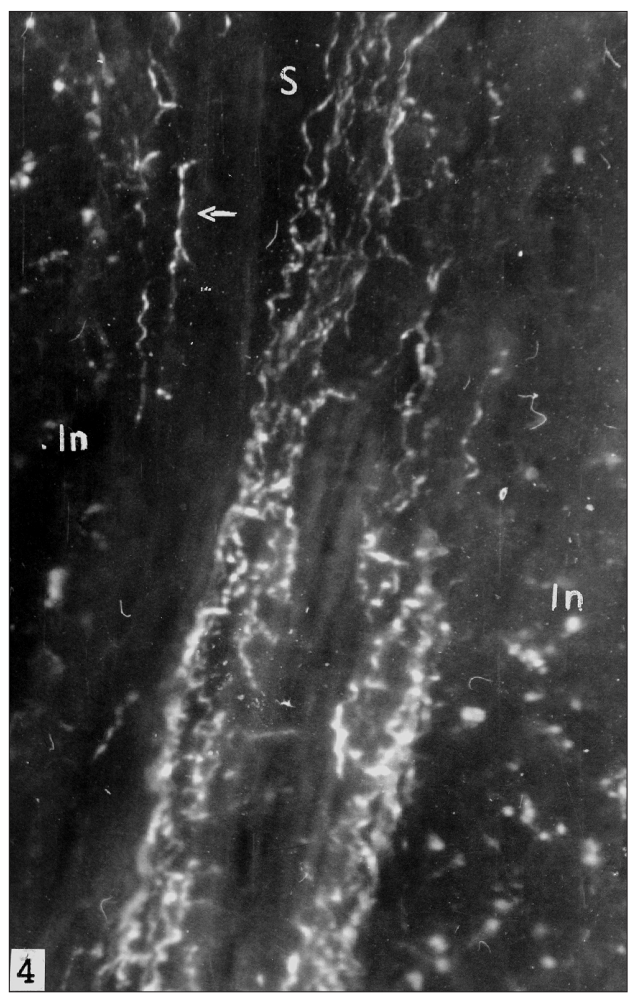

Fig. 4. Brightly specifically fluorescent adrenergic nerve profiles run together with dislocated arterial branch through the narrow internodular septum (S). Occurrence of delicate nerve fibres (arrow) is recorded in the marginal layers of the lymphoid follicle $(1 \mathrm{n})$; they do not penetrate inside their inner compartments (rabbit). Primary magnification: $\times 120$ 